\title{
Helicobacter pullorum in broiler chickens and the farm environment: A One Health approach
}

\author{
Soe Soe Wai ${ }^{1}$, Saleha Abdul-Azizi ${ }^{1}$ Asinamai Athliamai Bitrus ${ }^{1,2}$, Zakaria Zunita ${ }^{1}$ and Jalila Abu
}

1. Department of Pathology and Microbiology, Faculty of Veterinary Medicine, Universiti Putra Malaysia, 43400 UPM Serdang, Selangor, Malaysia; 2. Research Unit in Microbial Food Safety and Antimicrobial Resistance, Department of Veterinary Public Health, Faculty of Veterinary Science, Chulalongkorn University, 10330 Bangkok, Thailand.

Corresponding author: Saleha Abdul-Aziz; e-mail: saleha@upm.edu.my

Co-authors: SSW: aasaleha@yahoo.com, AAB: abasinamai@gmail.com, ZZ: zunita@upm.edu.my, JA: jalila@upm.edu.my Received: 13-11-2018, Accepted: 28-01-2019, Published online: 18-03-2019

doi: 10.14202/IJOH.2019.20-25 How to cite this article: Wai SS, Abdul-Aziz S, Bitrus AA, Zunita Z, Abu J. Helicobacter pullorum in broiler chickens and the farm environment: A One Health approach. Int J One Health 2019;5:20-25.

\section{Abstract}

Aim: This study aimed to investigate the occurrence of Helicobacter pullorum in broiler chickens and their farm environment.

Materials and Methods: The ceca from 100 broiler chickens from ten farms were sampled from processing sites or markets. The cecal contents were aseptically collected from each cecum and cultured. The farms were visited, and environmental samples were collected which included water, house flies, floor swabs and soils in chicken houses.

Results: H. pullorum was present in $51 \%$ of the broilers; $17.5 \%$ of the flies were found to carry H. pullorum and Campylobacter spp., $30 \%$ of house floors were positive, while all water samples were negative.

Conclusion: Flies could have picked up the organisms from the chickens' feces and/or the environment of the chicken houses or they could be one of the sources in the spread of the organisms. This study also showed that broiler chickens are potential reservoirs for H. pullorum and may serve as a source of infection for humans through the food chain.

Keywords: broiler chickens, Campylobacter, Helicobacter pullorum, house flies.

\section{Introduction}

Helicobacter pullorum is a common resident in the ceca of healthy poultry flocks such as broilers, laying hens, turkeys, and birds [1-3]. The organism has also been isolated from laying hens with avian hepatitis $[4,5]$. The modes by which these broiler chickens become colonized with $H$. pullorum have not been fully understood [6-8]. Several molecular epidemiologic studies showed that $H$. pullorum colonization may occur with a single strain that disseminates throughout the flock $[9,10]$.

Published data are lacking on the survival of $H$. pullorum outside the gastrointestinal niches. Helicobacter pylori and Campylobacter spp. have been shown to survive in water as viable but non-culturable organisms [11,12], and hence, water may also play a role in the transmission of $H$. pullorum to chickens in the farms. House flies have been reported to carry $H$. pylori and other enteric bacteria such as Salmonella [13-15] and Campylobacter in poultry flocks [16-18]. The transmission of the organisms is presumed to occur through small quantities of contaminated materials carried on the proboscis, legs, and

Copyright: Wai, et al. This article is an open access article distributed under the terms of the Creative Commons Attribution 4.0 International License (http://creativecommons.org/licenses/ by/4.0/), which permits unrestricted use, distribution, and reproduction in any medium, provided you give appropriate credit to the original author(s) and the source, provide a link to the Creative Commons license, and indicate if changes were made. The Creative Commons Public Domain Dedication waiver (http:// creativecommons.org/ publicdomain/zero/1.0/) applies to the data made available in this article, unless otherwise stated. body hairs or from materials regurgitated or defecated by the flies. Environmental sources, such as litter, feed, drinkers, and air, have been reported as having a potential role in the transmission of Campylobacter in poultry houses [14,19-23]. Ceelen et al. [24] isolated H. pullorum from farmers' boots. Therefore, environmental sources too may play an important role in the transmission of $H$. pullorum to chickens in the farms. Additionally, $H$. pullorum has also been reported to be associated with gastroenteritis, diarrhea, liver and gall bladder diseases as well as Crohn's disease in human patient [24].

In Malaysia, there is relatively very little information on the occurrence of $H$. pullorum in broiler chickens and the farm environment. Thus, this study aimed to determine the occurrence of $H$. pullorum in broiler chickens in the farm and to detect the presence of $H$. pullorum in the farm environment, namely water, flies, and floors and soils in the chicken houses.

\section{Materials and Methods}

\section{Ethical approval}

This study was performed as per the guidelines for the care and use of animals by Institutional Animal Care and Use Committee of Universiti Putra Malaysia and Animal Welfare Act.

\section{Sample collection}

The intestines of 100 chickens were collected from processing sites or markets. The ceca were carefully and aseptically removed from the intestine, placed in a sterile Petri dish, sealed with Parafilm, 
and kept in a cool box. Visits were made to the farms where the chickens were reared in 10 farms in different locations. Water samples were collected from various sources on the farm, which included tap water, well or groundwater, and drinkers. A total of 40 water samples (100 $\mathrm{mL}$ in each bottle) at four samples per farm were collected in sterile bottles. Flies in the poultry farms were collected using Glue Stick Fly Traps. Five flies were pooled in a bottle containing $1 \mathrm{~mL}$ of Brucella Broth (BD - Becton Dickinson and Co.). At least 10 flies were caught inside the farm, and another 10 flies were caught outside the farm within $50 \mathrm{~m}$ from the chicken houses. Each sample of floor swabs and soils fromclosed-house farms and floor swab samples from open-house farms were collected in a sterile bottle containing Brucella Broth (BD - Becton Dickinson and Co.). All samples were kept cool during transport to the Veterinary Public Health Laboratory, Faculty of Veterinary Medicine, Universiti Putra Malaysia. The samples were cultured within 4-6 $\mathrm{h}$ after sampling.

\section{Isolation of $\boldsymbol{H}$. pullorum}

Fresh cecal contents were obtained aseptically from the ceca of each chicken and subjected to the method of Miller et al. [25] which was slightly modified as described in Wai et al. [26]. Briefly, approximately $2 \mathrm{~g}$ of cecal contents were squeezed into $4 \mathrm{~mL}$ (1:2) of $0.85 \%$ sterile saline. Then, $100 \mu \mathrm{L}$ of the suspension was further diluted in $400 \mu \mathrm{L}$ of a sterile enrichment broth mixture (EBM) containing $25 \mathrm{~mL}$ of Brucella Broth (BD - Becton Dickinson and Co.), $5 \mathrm{~mL}$ of inactivated horse serum (Oxoid, UK), and $7.5 \mathrm{~g}$ of glucose (Sigma Chemical Co). Six drops of the aliquot in EMB were placed on $0.45-\mu \mathrm{m}$ pore size, sterile cellulose acetate membrane filter (Sartorius) which was earlier placed on $10 \%$ sheep blood agar (SBA) (Oxoid, UK) plate and incubated upright in a hydrogen-enriched microaerophilic atmosphere, generated using a gas generating pack BR0038B (Oxoid, UK) without palladium catalyst also recommended by le Roux and Lastovica [27], at $42^{\circ} \mathrm{C}$ for $1 \mathrm{~h}$ to allow passive filtration. Using sterile forceps, the filters were carefully removed, and the plates were incubated at $42^{\circ} \mathrm{C}$ for $48 \mathrm{~h}$ under the same atmospheric conditions as described above. The suspected colonies were selected and subcultured on SBA. Campylobacter jejuni ATCC 29428 and H. pullorum CCUG 33837 and ATCC 51863 were used as reference strains. All field isolates and reference strains were stored at $-20^{\circ} \mathrm{C}$ and $-80^{\circ} \mathrm{C}$, respectively.

Isolation of $H$. pullorum from water samples was carried out as per the method described by Diergaardt et al. [28]. Briefly, $100 \mathrm{~mL}$ of each water sample was filtered; then, the filter was rolled, placed in a sterile bottle containing $9 \mathrm{~mL}$ of EBM, and incubated at $42^{\circ} \mathrm{C}$ for $24 \mathrm{~h}$ under similar condition described previously. After incubation, $250 \mu \mathrm{L}$ of the culture in EBM was dropped onto the surface of a membrane filter placed earlier on SBA surface. Similar procedure as described above was used for the isolation of H. pullorum from water samples. The pooled samples of flies in each bottle were crushed, and $2 \mathrm{~mL}$ of EBM was added. The procedure for the isolation of $H$. pullorum from flies and floor swab samples was similarly carried for cecal contents.

\section{Phenotypic identification of $\boldsymbol{H}$. pullorum}

All suspected $H$. pullorum colonies were examined for phenotypic characteristics (Gram-negative, slightly curved, slender rod) and subjected to oxidase, catalase, and indoxyl acetate hydrolysis tests for presumptive identification. The motility of the isolates was determined by phase-contrast microscopy of a wet mount prepared from cultures. Other phenotypic identification was hippurate hydrolysis test, sensitivity to polymyxin $\mathrm{B}$ and nalidixic acid, resistance to cephalothin, and growth at $25^{\circ} \mathrm{C}, 37^{\circ} \mathrm{C}$ and $42^{\circ} \mathrm{C}$ in aerobic, anaerobic, and microaerobic conditions.

\section{Genotypic identification of $\boldsymbol{H}$. pullorum}

A single presumptive Helicobacter colony was streaked onto SBA and incubated at $42^{\circ} \mathrm{C}$ for $48 \mathrm{~h}$ under similar atmosphere mentioned above. A few colonies were taken and washed in $1 \mathrm{~mL}$ Brucella Broth (BD - Becton Dickinson and Co.), in a $1.5 \mathrm{~mL}$ sterile microcentrifuge tube. The extraction of genomic DNA was done per DNeasy Blood and Tissue DNA Purification Kit (QIAGEN). The quality of the extracted DNA was accessed using spectrophotometer and gel electrophoresis. The resulting DNA pellet with desirable quality was stored at $-20^{\circ} \mathrm{C}$ until used. Confirmation of the presumptive isolates was done using a modified species-specific polymerase chain reaction (PCR) assay as described by Miller et al. [25]. The primers used were forward primer 5'-ATGAATGCTAGTTGTTGTGAG-3' and reverse primer 5'-GATTGGCTCCACTTCACA-3'. A total of $1 \mu \mathrm{L}$ of DNA preparation was added to a $20 \mu \mathrm{L}$ (final volume) reaction mixture containing $0.25 \mu \mathrm{M}$ of each primer and Maxime PCR Premix Kit (iStarTaq) (iNtRON Biotechnology, Korea). The PCR product was then incubated with initial denaturation at $94^{\circ} \mathrm{C}$ for $4 \mathrm{~min}$, followed by 30 cycles of $93^{\circ} \mathrm{C}$ for $1 \mathrm{~min}$, annealing at $65^{\circ} \mathrm{C}$ for $1 \mathrm{~min}$, and extension at $72^{\circ} \mathrm{C}$ for $1 \mathrm{~min}$ with a final incubation at $72^{\circ} \mathrm{C}$ for $5 \mathrm{~min}$. A $5 \mu \mathrm{L}$ of the PCR product was electrophoresed through a $2 \%$ agarose gel containing Tris-BorateEDTA (TBE) buffer ( $40 \mathrm{mmol} / 1$ tris-borate, $2 \mathrm{mmol} / 1$ EDTA, $\mathrm{pH} 7.5)$ and gel red $(3 \mu \mathrm{L} / \mathrm{mL})$ in TBE buffer at $75 \mathrm{~V}$, for $80 \mathrm{~min}$. The gel was viewed by ultraviolet (UV) transillumination.

Multiplex PCR (m-PCR) was performed to further identify the presumptive mixed isolates of $H$. pullorum and Campylobacter species. The primers used to detect Campylobacter were for Campylobacter genus specific: Forward C99-GCGTGGAGGATGACACCT and reverse C98-GATTTTACCCCTACACCA and for $H$. pullorum species-specific mentioned as above. 
PCR amplifications were performed as described earlier; however, the annealing temperature used was $55^{\circ} \mathrm{C}$ as mentioned in Shen et al. [29].

\section{Results and Discussion}

The colonies of suspected $H$. pullorum were very small, pinpoint, translucent, hemolytic, and some were a watery film like. They were Gram-negative, motile (spiral, slow-jerky-tumbling motility under wet mount), and oxidase and mostly catalase positive (isolates from one farm were catalase negative) and all were negative to indoxyl acetate hydrolysis and hippurate hydrolysis tests. Several suspected isolates were observed to show a weak reaction to indoxyl acetate hydrolysis test. All isolates were resistant to cephalothin and sensitive to polymyxin B, and $84.3 \%$ were resistant to nalidixic acid. The suspected $H$. pullorum isolates and the reference strain $H$. pullorum ATCC 51863 yielded a single band at 447 bp (Figure-1), whereas the reference strain C. jejuni ATCC 24928 did not show any band in the H. pullorum species-specific PCR assay. The phenotypic and PCR results provided evidence that the suspected isolates were H. pullorum. Of the 100 broiler chickens sampled, $51(51 \%)$ were positive for $H$. pullorum. Pure isolates of $H$. pullorum were obtained from 45 of 51 positive samples from seven farms. One farm (farm 18) had six of ten positive samples which were co-colonized with Campylobacter species. Two farms were negative for H. pullorum; these two farms (farms 16 and 17) were under closed-housing system (Table-1). In the $\mathrm{m}$-PCR assay, all the suspected isolates showed bands at $447 \mathrm{bp}$ and $296 \mathrm{bp}$, exactly to that of the reference strain $H$. pullorum ATCC 51863 and C. jejuni ATCC 24928, respectively (Figure-2). It was noted that each isolate with weak indoxyl hydrolysis test results showed that it consisted of H. pullorum and Campylobacter spp. which could not be separated on repeated subcultures.

All the 40 water samples were negative for H. pullorum (Table-2). Of the 40 bottles containing pooled fly samples, seven $(17.5 \%)$ from three farms were positive and found to carry $H$. pullorum and Campylobacter spp. (Figure-2 and Table-3). Six $(30 \%)$ of floor and soil swab samples from three farms were positive and consisted of $H$. pullorum and Campylobacter spp. (Figure-2 and Table-3). The flies and floor samples from three farms $(9,11$, and 12) were positive for H. pullorum and Campylobacter spp. Farms 14 and 15 had low occurrences probably due to better environmental conditions.

The study also showed that H. pullorum was prevalent in broiler chickens in the farms. Previous studies showed high occurrences of $H$. pullorum in chickens ranged from $60 \%$ in the UK [30] to $78.3 \%$ in the Czech Republic [31], $100 \%$ in Italy [2], and France [32]. However, some studies showed low-to-moderate isolation rates which ranged from $4 \%$ in Switzerland [5] to $13.5 \%$ in Australia [25], 33.6\% in Belgium [10],

\section{$\begin{array}{lllllllllllll}1 & 2 & 3 & 4 & 5 & 6 & 7 & 8 & 9 & 1011 & 12 & 13 & 14\end{array}$}

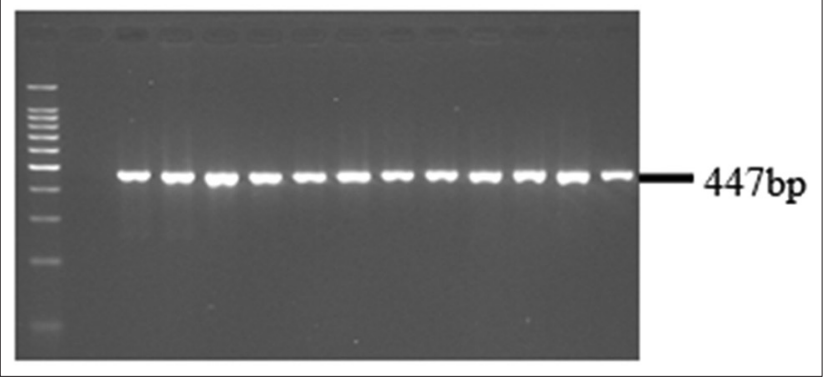

Figure-1: Modified species-specific polymerase chain reaction for Helicobacter pullorum. Lane: 1 - marker 100 bp ladder lane, 2 - Campylobacter jejuni ATCC 24928 lane, 3 - H. pullorum ATCC 51863 lane, 4-14 - H. pullorum isolates.

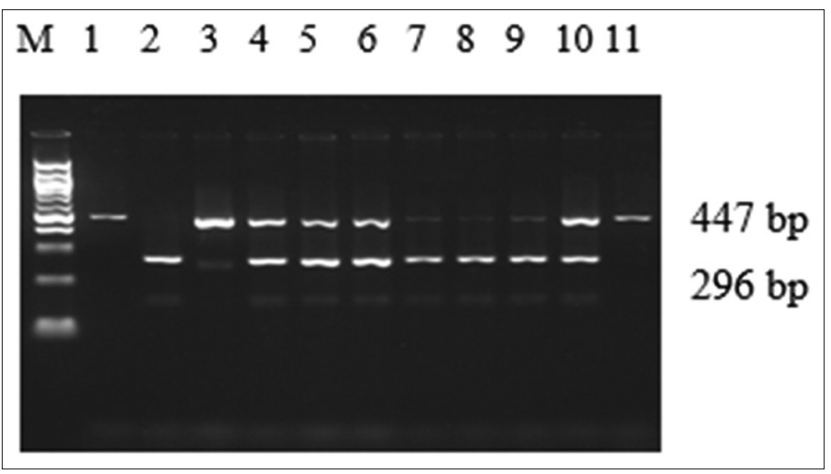

Figure-2: Modified polymerase chain reaction for Helicobacter pullorum and Campylobacter spp. Lane M - marker 100 bp ladder; lanes: 1 - H. pullorum ATCC 51863, 2 - Campylobacter jejuni ATCC 24928, 3 - H. pullorum CCUG 33837, 4-6 mixed isolates from fly samples, 7-9 mixed isolates from floor samples, 10 - mixed isolate from broiler samples, $11-H$. pullorum ATCC 51863.

Table-1: Occurrence of $H$. pullorum in broiler chickens in 10 farms.

\begin{tabular}{lcccc}
\hline Farms & $\begin{array}{c}\text { Number of } \\
\text { samples }\end{array}$ & \multicolumn{2}{c}{ Isolations } & $\begin{array}{c}\text { Number of } \\
\text { positives (\%) }\end{array}$ \\
\cline { 3 - 4 } $\boldsymbol{H . p}$ & Mix* & \\
\hline 9 & 10 & 8 & 0 & $8(80)$ \\
10 & 10 & 9 & 0 & $9(90)$ \\
11 & 10 & 8 & 0 & $8(80)$ \\
12 & 10 & 8 & 0 & $8(80)$ \\
13 & 10 & 7 & 0 & $7(70)$ \\
14 & 10 & 3 & 0 & $3(30)$ \\
15 & 10 & 2 & 0 & $2(20)$ \\
16 & 10 & 0 & 0 & $0(0)$ \\
17 & 10 & 0 & 0 & $0(0)$ \\
18 & 10 & 0 & 6 & $6(60)$ \\
Total & 100 & 45 & 6 & $51(51)$ \\
\hline
\end{tabular}

H.p=Helicobacter pullorum; *Mix: Mixed culture consisting of H. $p$ and Campylobacter spp. Farms 9-15 and 18 practiced open-house system; Farms 16 and 17 practiced closed-house system

and 39.3\% in Egypt [8]. Manfreda et al. [33] found that chickens reared in free-range farms had lower occurrence $(57 \%)$ compared to those reared in conventional $(84 \%)$ and organic $(97 \%)$ farms, warranted further investigation by the authors. In this study, the presence of the organisms in chickens was probably 
Table-2: Occurrence of $H$. pullorum isolates in broiler chickens and environmental samples in 10 farms.

\begin{tabular}{lcccc}
\hline Farms & Chickens & Flies & Floor & Water \\
\hline 9 & + & + & + & - \\
10 & + & - & - & - \\
11 & + & + & + & - \\
12 & + & + & + & - \\
13 & + & - & - & - \\
14 & + & - & - & - \\
15 & + & - & - & - \\
16 & - & - & - & - \\
17 & - & - & - & - \\
18 & + & - & - \\
\hline
\end{tabular}

+Positive for $H$. pullorum, -negative for $H$. pullorum. H. pullorum $=$ Helicobacter pullorum

Table-3: Occurrence of $H$. pullorum in water, flies, and floor and soil.

\begin{tabular}{lccc}
\hline Type of samples & $\begin{array}{c}\text { Number of } \\
\text { samples }\end{array}$ & \multicolumn{2}{c}{$\begin{array}{c}\text { Number of positive } \\
\text { isolates (\%) }\end{array}$} \\
\cline { 3 - 4 } & & H.p & Mix* \\
\hline Water & 40 & 0 & $0(0.0)$ \\
Flies & 40 & 0 & $7(17.5)$ \\
Floors and soils & 20 & 0 & $6(30.0)$ \\
\hline
\end{tabular}

H.p: Helicobacter pullorum; *Mix: Mixed culture

consisting of H.p and Campylobacter spp.

due to the unhygienic condition of housing facilities, high fly populations, presence of wild birds and rats around farm environment and in chicken houses, and lack of biosecurity measures such as absence of footbath and presence of water puddles under some of the chicken houses which were observed during the study. The presence of Campylobacter spp. together with $H$. pullorum was found on one farm. Shen et al. [29] had reported the simultaneous presence of Helicobacter spp. and Campylobacter spp. in cats.

It is interesting to note that $H$. pullorum was not isolated from chickens in two farms which practiced closed-housing system. It is most likely due to good hygiene and husbandry practices, and birds, as well as insects, had no access to the chicken houses. Furthermore, the environmental samples collected from these farms were also negative for $H$. pullorum. A similar finding was reported by Tang et al. [34] who did not isolate any Campylobacter in chickens in closed-housing system compared to $95 \%$ in chickens reared under open-housing system. Bull et al. [23] showed that the transmission of Campylobacter spp. can occur from puddles outside the facility to broiler flocks, feed, water, litter, and air within the house despite the implementation of standard biosecurity measures in modern broiler house.

In this study, H. pullorum was not present in the water samples. Azevedo et al. [12] reported that all Helicobacter spp. were sensitive to light and temperature $\left(37^{\circ} \mathrm{C}\right)$ and all tested strains lost their culturability within $24 \mathrm{~h}$ of exposure. UV rays and higher temperatures $\left(>42^{\circ} \mathrm{C}\right)$ have been shown to destroy and even kill Campylobacter cells [28]. The absence of $H$. pullorum in water as well as in the environment may not only be due to a small number of $H$. pullorum in the sampled water but may also be due to presence of contaminating robust microorganisms or the organisms were in nonculturable but viable form could be inactivated due to warm temperature. In most of the open-house farms, the water tanks were not covered and readily exposed to warm temperature $\left(37^{\circ} \mathrm{C}\right)$. The uncovered water tanks were exposed to high temperature and UV which may have contributed to the absence of viable $H$. pullorum in water and farm environments.

Flies from three farms that practiced open-housing system were found co-colonized with $H$. pullorum and Campylobacter spp. Rosef and Kapperub [16] isolated Campylobacter from $50.7 \%$ of flies in broiler farms, while Hald et al. [18] found an 8.2\% carriage rate of $C$. jejuni in flies captured in ventilation inlets of broiler house. H. pylori in flies was reported to serve as a reservoir and a vector to chickens and man as well as the environment [13]. From this study, it may be possible that flies may have had a role as reservoirs in the spread H. pullorum and Campylobacter to chickens in the farms or on having in contact with the organisms from the chickens and/or the contaminated environment may had disseminated the organisms. Apart from flies, wild birds have also been reported to carry Campylobacter and H. canadensis, a probable zoonotic pathogen and closely related to H. pullorum [35]. Wild birds were observed around and in the chicken houses in the open-housing system. The floor samples in three open-house farms too were contaminated with $H$. pullorum and Campylobacter spp. It could be that the organisms shed in the feces had contaminated the floors and soils. The potential role of litter in the transmission of Campylobacter in poultry house from infected chicks was described by Montrose et al. [19]. Further study is recommended to investigate the role of environment in the spread of H. pullorum. The study also showed a high occurrence of $H$. pullorum, indicating that they may be a frequent intestinal colonizer of broiler chickens and thus may represent a health risk to humans.

\section{Conclusion}

This study provided further information on the occurrence and spread of $H$. pullorum in poultry. The closed-housing system showed that good biosecurity measures and good management and husbandry practices could minimize or control the presence of H. pullorum and Campylobacter spp. in broiler chickens and the farm environment; thus, the establishment of more of such farms is highly recommended.

\section{Authors' Contributions}

SA conceived and designed the study. SSW and JA collected the samples and SSW carried out the experiment. AAB, SSW, and $\mathrm{ZZ}$ analyzed the data. SSW wrote the first draft of the manuscript. SA and 
$\mathrm{AAB}$ revised the manuscript. All authors read and approved the final draft of the manuscript.

\section{Acknowledgments}

The authors wish to thank the staff of Veterinary Public Health Laboratory, Faculty of Veterinary Medicine, Universiti Putra Malaysia for their technical assistance. This research study was supported by Science fund Research Grant from Ministry of Agriculture, Malaysia (Project No. 5450205).

\section{Competing Interests}

The authors declare that they have no competing interests.

\section{Publisher's Note}

Veterinary World remains neutral with regard to jurisdictional claims in published institutional affiliation.

\section{References}

1. Javed S, Gul F, Javed K, Bokhari H. Helicobacter pullorum: An emerging zoonotic pathogen. Front Microbiol 2017;8:604.

2. Borges V, Santos A, Correia CB, Saraiva M, Ménard A, Vieira L, et al. Helicobacter pullorum isolated from fresh chicken meat: Antibiotic resistance and genomic traits of an emerging foodborne pathogen. Appl Environ Microbiol 2015;81:8155-63.

3. Hamada M, Elbehiry A, Marzouk E, Moussa IM, Hessain AM, Alhaji JH, et al. Helicobacter pylori in a poultry slaughterhouse: Prevalence, genotyping and antibiotic resistance pattern. Saudi J Biol Sci 2018;25:1072-8.

4. Mladenova-Hristova I, Grekova O, Patel A. Zoonotic potential of Helicobacter Spp. J Microbiol Immunol Infect 2017;50:265-9.

5. Burnens AP, Stanley J, Nicolet J. Possible association of Helicobacter pullorum with lesions of vibrionic hepatitis in poultry. In: Newell DG, Ketley JM, Feldman RA, editors. Campylobacters, Helicobacters and Related Organisms. New York: Plenum Press; 1996. p. 291-4.

6. Sheh A, Shen Z, Fox JG. Draft genome sequences of eight enterohepatic Helicobacter species isolated from both laboratory and wild rodents. Genome Announc 2014;2:e01218-14.

7. Parente MR, Monteiro JT, Martins GG, Saraiva LM. Helicobacter pullorum induces nitric oxide release in murine macrophages that promotes phagocytosis and killing. Microbiology 2016;162:503-12.

8. Jervis AJ, Wood AG, Cain JA, Butler JA, Frost H, Lord E, et al. Functional analysis of the Helicobacter pullorum N-linked protein glycosylation system. Glycobiology 2018;28:233-44.

9. Wai SS, Saleha AA, Zunita Z, Hassan L, Jalila A, Shah AH. Genetic relatedness among Helicobacter pullorum isolates from broiler chickens. Int J Poult Sci 2014;13:240-5.

10. Ceelen LM, Decostere A, Van den Bulck K, On SL, Baele M, Ducatelle R, et al. Helicobacter pullorum in chickens, Belgium. Emerg Infect Dis 2006;12:263-7.

11. Watson CL, Owen RJ, Said B, Lai S, Lee JV, Surman-Lee S, et al. Detection of Helicobacter pylori by PCR but not culture in water and biofilm samples from drinking water distribution systems in England. J Appl Microbiol 2004;97:690-8.

12. Azevedo NF, Almeida C, Fernandes I, Cerqueira L, Dias S, Keevil CW, et al. Survival of gastric and enterohepatic Helicobacter spp. In water: Implications for transmission. Appl Environ Microbiol 2008;74:1805-11.

13. Junqueira AC, Ratan A, Acerbi E, Drautz-Moses DI,
Premkrishnan BN, Costea PI, et al. The microbiomes of blowflies and houseflies as bacterial transmission reservoirs. Sci Rep 2017;7:16324.

14. Qumar S, Majid M, Kumar N, Tiwari SK, Semmler T, Devi S, et al. Genome dynamics and molecular infection epidemiology of multidrug-resistant Helicobacter pullorum isolates obtained from broiler and free-range chickens in India. Appl Environ Microbiol 2017;83:e02305-16.

15. Bahrndorff $\mathrm{S}$, de Jonge $\mathrm{N}$, Skovgård $\mathrm{H}$, Nielsen JL. Bacterial communities associated with houseflies (Musca domestica L.) sampled within and between farms. PLoS One 2017;12:e169753.

16. Rosef O, Kapperud G. House flies (Musca domestica) as possible vectors of Campylobacter fetus subsp. Jejuni. Appl Environ Microbiol 1983;45:381-3.

17. Shane SM, Montrose MS, Harrington KS. Transmission of Campylobacter jejuni by the housefly (Musca domestica). Avian Dis 1985;29:384-91.

18. Hald B, Skovgård H, Bang DD, Pedersen K, Dybdahl J, Jespersen JB, et al. Flies and Campylobacter infection of broiler flocks. Emerg Infect Dis 2004;10:1490-2.

19. Montrose MS, Shane SM, Harrington KS. Role of litter in the transmission of Campylobacter jejuni. Avian Dis 1985;29:392-9.

20. Kaakoush NO, Sodhi N, Chenu JW, Cox JM, Riordan SM, Mitchell HM, et al. The interplay between Campylobacter and Helicobacter species and other gastrointestinal microbiota of commercial broiler chickens. Gut Pathog 2014;6:18.

21. Jamshidi A, Bassami MR, Salami H, Mohammadi S. Isolation and identification of Helicobacter pullorum from caecal content of broiler chickens in Mashhad, Iran. Iran J Vet Res 2014;15:179-82.

22. Markos T, Abdela N. Epidemiology and economic importance of pullorum disease in poultry: A review. Glob Vet 2016;17:228-37.

23. Bull SA, Allen VM, Domingue G, Jorgensen F, Frost JA, Ure R, et al. Sources of Campylobacter spp. Colonizing housed broiler flocks during rearing. Appl Environ Microbiol 2006;72:645-52.

24. Ceelen LM, Decostere A, Verschraegen G, Ducatelle R, Haesebrouck F. Prevalence of Helicobacter pullorum among patients with gastrointestinal disease and clinically healthy persons. J Clin Microbiol 2005;43:2984-6.

25. Miller KA, Blackall LL, Miflin JK, Templeton JM, Blackall PJ. Detection of Helicabacter pullorum in meat chicken in Australia. Aust Vet J 2006;84:95-7.

26. Wai SS, Saleha AA, Zunita Z, Hassan L, Jalila A. Occurrence of co-infection of Helicobacter pullorum and Campylobacter spp. In broiler and village (indigenous) chickens. Pak Vet J 2012;32:503-6.

27. Le Roux E, Lastovica AJ. The cape town protocol: How to isolate the most Campylobacter from your dollar, pound, franc, yen, etc. In: Lastovica AJ, Newell DG, Lastovica EE, editors. Campylobacter, Helicobacter and Related Organisms. Cape Town: Institute of Child Health; 1998. p. 30-3.

28. Diergaardt SM, Venter SN, Spreeth A, Theron J, Brözel VS. The occurrence of campylobacters in water sources in South Africa. Water Res 2004;38:2589-95.

29. Shen Z, Feng Y, Dewhirst FE, Fox JG. Coinfection of enteric Helicobacter Spp. And Campylobacter spp. In cats. J Clin Microbiol 2001;39:2166-72.

30. Sergeant MJ, Constantinidou C, Cogan TA, Bedford MR, Penn CW, Pallen MJ, et al. Extensive microbial and functional diversity within the chicken cecal microbiome. PLoS One 2014;9:e91941.

31. Svobodova I, Boribova G. Incidence of Helicobacter pullorum and Campylobacter spp. In healthy broilers in the Czech republic. Zoo Public Health 2003;54:75.

32. Pilon C, Prouzel-Mauléon V, Ménard A, Mégraud F. Development of a Real-Time Quantitative PCR Specific to Helicobacter pullorum. Gold Coast, Queensland, Australia: Thirteenth International Workshop on Campylobacter, 
Helicobacter and Related Organisms (CHRO): Abstracts of Scientific Presentations, September 4-8 ${ }^{\text {th }}$; 2005. p. 62.

33. Manfreda G, Parisi A, Lucchi A, Zanoni RG, Cerare AD. Prevalence of Helicobacter pullorum in conventional, organic and free-range and typing of isolates. Appl Environ Microbiol 2011;77:479-84.

34. Tang JY, Saleha AA, Jalila A, Farinazleen MG, Tuan ZT,
Noorlis A, et al. Thermophilic Campylobacter spp. Occurrence on chickens at farm, slaughterhouse and retail. Int J Poult Sci 2010;9:134-8.

35. Shen Z, Sheh A, Young SK, Abouelliel A, Ward DV, Earl AM, et al. Draft genome sequences of six enterohepatic Helicobacter species isolated from humans and one from rhesus macaques. Genome Announc 2014;2:e00857-14.

$* * * * * * * *$ 